\title{
Systematic Literature Review: Implications of Mental Illness on Life and Working Integrity
}

\author{
Nor Shela Saleha, and Mohd Shafie Rosli ${ }^{\mathrm{b}}$ \\ A \\ Centre for General Studies and Co-Curricular, Universiti Tun Hussein Onn \\ Malaysia, 86400, Parit Raja Batu Pahat, Johor \\ ${ }^{\mathbf{b}}$ School of Education, Faculty of Social Sciences and Humanities, Universiti \\ Teknologi Malaysia, 81310, Skudai Johor Bahru, Johor
}

Article History: Received: 11 January 2021; Accepted: 27 February 2021; Published online: 5 April 2021

\begin{abstract}
Mental health problems in society are becoming new and more distressing as explained by the Ministry of Health Malaysia and the World Health Organization. Mental problems occur amongst working adults, the elderly, adolescents and children, men and women. Recent research confirms that the causes of mental health problems are due to genetic problems, personal problems, financial problems, learning pressures and stress at workplace. The effects of mental health problems can lead to depression, emotional tension, personality disorder and suicide. In order to obtain a wealth of information, researchers have accompanied critical analysis studies by viewing at several empirically established from previous studies. The first finding shows that mental illness classified as a brain disorder, an emotional disorder and an abnormal attitude. The second finding explains that the level of mental health knowledge among students is still low. The third study examines the causes of schizophrenia, which have four causes of the disease, namely genetic factors, drugs, work stress and poverty. The fourth finding explains the experience of caring for a mentally ill person who is also having trouble in the life of the patient's family. Generally, this study explains that mental illness is a problem that has various negative effects on various people. Implications of mental illness transpire over the long term if treatment not properly performed. Therefore, proactive initiatives prerequisite to be taken by all parties to ensure the quality of life of the people will perfect and normal devoid of interruption of mental illness.
\end{abstract}

Keywords: Mental Health, Mental Illness, Depression, Personality Disorders, Work Pressure

\section{Introduction}

The development of a country depends on the integrity and maturity of its people. Healthy societies have a well-balanced mind as well as a holistic ability to produce a variety of things and agendas. Consequently, the development, progress and development of globalization have been a challenge to all individuals in realizing their potential for self and quality of life. In realizing and reaching all aspects of the globalization vision, humans have to become the movers and sources of human capital (Zafir \& Fazilah, 2006). These insights, objectives, visions and missions diligently linked to the organization's goals in enhancing their company's competencies. Organizational goals frequently push for human resources, leading superiors to press subordinates to carry out their agenda planning (Noraini \& Noorasmah, 2019). Determinations and responsibilities that categorized as commitments do indeed contribute to high levels of stress. Particularly subordinate workers will be assigned and perform such tasks as the superior. Power and mind numbing can have a negative effect if it is not properly controlled and planned.

The reality of life and stress in the workplace is largely due to the function and role of individual. They suffer from stress, depression and eventually tension affects their quality of life. Low quality of life can affect physical pain as well as emotional haste. If this not treated for a long time, it can lead to chronic mental illness. Therefore, the source of pressure identified. For example, in the context of stress in the workplace, it is associated with employee anxiety and discomfort in carrying out work. In the study of Nur Izzaty et al. (2015), stress in the workplace influenced by the quantity and burden of work tolerated by workers. In fact, the ambiguity of the task and the role strongly stimulates the employee's emotions and stress (Gallie \& Russell, 2009). Therefore, the twoway communication between top management and subordinates is essential to ensure that employees kept safe while performing tasks effectively and efficiently.

\section{Problem Statement}

Human well-being evidenced by normal behaviour and constant emotions. Emotional weakness is one of the first signs that a person is depressed and heading towards mental illness. Therefore, depression is one of the contributing factors to the risk of stress and mental illness (Ismail et al., 2013). Amongst the several nature of careers that lead to depression are the fields of teaching, nursing and customer service at risk of contributing to depression dominantly amongst female workers. The stress-contributing factor is due to the exhaustion of commuting workers from remote locations. In fact, there are work conflicts between family and career commitments that are stressful and create emotional tension for workers.

Scientifically, individuals who exposed to stress have many immune disorders (Mojoyinolo, 2008). Consumption disorders and unhealthy lifestyle early in life can be a contributing factor to persistent pressure. Wan 
Noor Hayati's (2016) report found children's lifestyle correlates with stress in adolescence. This is due to the parents' weakness in providing their children with the appropriate education and affection. If this problem is not controlled, it will endanger the lives of children and adolescents. Finally, the statistics on mental illness rates are increasing. In a statement by a psychologist, Associate Professor of Psychiatry, it explained in Zubir's (2018) report that the problem of mental illness would become chronic in 10 years. $40 \%$ of Malaysians are currently suffering from depression. The dominance of depression is also among women. Among the contributing factors to mental illness because of depression are family history of depression.

Government has to take systematic initiatives to ensure that the issue of mental illness remains under control. However, Malaysia has only 380 psychiatrists, despite the necessity for around 3000-trained doctors. According to Nursyazlin and Noraini (2017), the need for specialists in the field of psychology and low mental health can reduce the number of patients in the country. The treatment method should have tailored to the requirements of the patient. Each patient should have treated in stages until healing. The diagnosis phase is an important phase for assessing and identifying the level of mental illness of the patient before follow-up treatment (Masilamani et al., 2013). Unfortunately, a lack of professionalism will hamper the treatment and probability of the number of patients recovering.

The risks and implications of accelerated treatment of mental patients have a significant negative impact on the economy of the country. It has reported in a study abroad that several companies suffer from the loss of their employees (Zafir \& Fazilah, 2006). Workplace stress is a burden and requires the company to provide compensation and treatment to employees in the event of a workplace accident. In 2000, the United Kingdom recorded a 33 percent increase in claims related to workplace accidents.

In the context of the community, suicidal tendencies are often associated with depression patients. According to information released by Health Director-General Datuk Dr Noor Hisham Abdullah, the World Health Organization (WHO) found suicide records as the top 10 causes of death in the world. These facts prove that stress is a dangerous disease and is consistent with the worldwide statistics of chronic illness (Siti Aisyah, 2019). The impact of suicide will not only affect the individual but it will also affect the image and reputation of the victim's family. According to Siti Aisyah's report (2019), the Ministry of Health Malaysia provided mental health screening and treatment services at 60 government hospitals, 1001 health clinics and 25 Mental Health Community Centres (MENTARI).

\section{Research Objectives}

3.1 To identify the concept and monitoring of mental illness

3.2 To identify the knowledge level of mental health

3.3 To identify schizophrenia mental disease factors

3.4 To identify family experience care for mental illness person

\section{Literature Review}

For deep explanation, researcher will have discussed and explain about four elements were mention in this research. The four elements are the classification of mental illness, an issues about mental health among students, the developing and factor of schizophrenia mental and family issues about mental illness.

\subsection{Classification of Mental Illness}

According to the dictionary statement and definition (1984), stress is associated with emotional pressures that force an individual to bear an unbearable burden. Simple pressure can cause physical and emotional problems that can lead to psychosomatic and physiological pain (Nur Izzaty et al., 2015). There are numbers of factor contribute to stress and mental illness. According to Firdaus's (2019) report, the National Institute of Occupational Safety and Health (NIOSH) in the United States found that nearly one-third of workers are under stress at work. Similarly, in Europe, records show that around 20 to 30 percent of workers are depressed. Causes of stress are largely due to individual problems, conflicts between people and unpleasant environmental factors. In the context of occupational safety and health, this problem is often associated with the structure of the body's working position especially when using a computer. The position and spot of the body and its members are not conducive to over-fatigue and tiredness which can suppress emotions and lead to mental pain.

Implementation of uncontrolled tasks contributes to increased levels of human stress (Asri \& Hamrila, 2007). Tasks that exceed capacity will reason people to feel overwhelmed and distracted. Indirectly, they initiate to feel uninterested and unhappy while carrying out their tasks. It could be a mental health problem or even considered senseless. However, according to (Zuraimi, Azizi \& Mohd Nor, 2016), stress will only exist if the burden and capacity of work exceed one's capacity. The context of this ability encompasses the ability and competence of a person to manage with a given task. The restrictions and capabilities of an individual depend on the potential and skill of the individual to accomplish the assigned task.

Uncertainty thrilling pressure problems occur over the long term, it will ruin an employee's potential. Work commitment disrupted. Therefore, the role of employers is very important in addressing this issue (Noraini \& Noorasmah, 2019). Increased burden will also give rise to internal conflicts in the event of unsystematic distribution of tasks (Lazarus, 1990). This is due to the attitude of the employer or the manager who sets the rate of employment different between the workers. This phenomenon often causes workers to quarrel and 
dissatisfaction with each other. Prolonged conflicts in the workplace interfere with work and emotional well-being and lead to depression, stress and mental illness.

Mental health issues among individuals have gained a lot of coverage and research worldwide. Preliminary in 1992, World Mental Health Day set for October 10 each year with a variety of theme celebrations. According to a report in Firdaus (2019), the 2015 National Health and Morbidity Survey study found that 29.2 percent of Malaysians suffer from mental stress and anxiety. In talking about this issue, the government is always optimistic and concerned about mental health matters. Among the projects and actions undertaken are to conduct mental health screening programs worldwide (Firdaus, 2019). Various approaches and methods implemented to ensure that mental screening performed to meet the criteria of testing one's mental health.

\subsection{Mental Health amongst Students}

Salmah (2009) mention that mental health problems are not trivial and easy to control. This be able impact life threatening and reason the death if not treated promptly. According to Nursyazlin and Noraini (2017) early childhood problems treated if, parents are conscious and aware of their children's behaviour and emotional changes. Technological changes, innovations and needs in the world market have made the demands of human life more challenging. An urgent challenge not only causes fatigue, but also stresses it if it fails to cope positively. Azlina (2012) explains that the issue of mental illness needs taken into account, as if cannot classified abstractly if detailed treatment done properly.

Failure to control and balance life will affect an individual's emotions. It has also been proven in the study of Zafir and Fazilah (2006) that the problem of failure to control emotionally is likely to affect Cumulative Trauma Disorder. Cumulative Trauma Disorders are more often associated with problems at workplace. The style and position of the body posture during non-ergonomic work can cause excessive pain and self-harm. Deprived of body position reassures organs and nerves to become tired, leading to headaches and emotions. This disruption will also affect the quality of daily sleep (Nursyazlin \& Noraini, 2017).

Wan Noor Hayati's (2016) report shows that the stress and problems of mental illness are largely due to individual and genetic background. Most children experience childhood depression because of environmental factors, school, family, teachers and friends. Undeniably, genetic factors are also among the contributors to stress in children. The attitude of some parents biased or overly aggressive cause's children to feel unsafe and often has a problem. Families with frequent engagements and conflicts interfere with children's emotional development. Children will remember the problems they faced in childhood and will develop into traumatic experiences.

In a commentary previously presented by Child and Adolescent Psychiatric Consultants, Dr Ramli Mohd Ali explained that a hyperactive student referred to a psychiatrist for professional counselling services from the appropriate person (Wan Noor Hayati, 2016). This problem needs to addressed, as it is not a minor issue as it delayed to the future. Today, the 2015 National Health Morbidity Survey (NHMS) found that 600000 children between the ages of five and 16 have suffered from mental health problems. Some of the factors that because depression include health problems, self-management conflicts, financial problems, personal and family issues and other related issues (Wan Noor Hayati, 2016).

To ensure the quality of mental health, the community constantly urged to adopt a healthy routine and lifestyle in line with the recommendations of the Ministry of Health Malaysia. Implementing a healthy lifestyle and balanced nutrition techniques are essential in ensuring the quality of human life. Several individuals have to tolerate the burden of stress over the years due to their failure to control their emotions (Zubir, 2018). It is even more distressing when such pressures take over the human body and cause a great deal of destruction to themselves. Even pressure can cause people to be hallucinating and to have a psychologist in them. In addition to chronic illnesses, especially cancer and so on, many mental patients suffer from personality disorders including seven different personalities. Different personalities are one of the mental problems that need to be treated (Alina et al., 2020).

\subsection{Schizophrenia Mental}

Schizophrenia is a type of mental illness that involves changes in behaviour. Patients with behavioural changes repeatedly show emotional distress, failure to interact well, hallucinations and delusions. Failure to control this disease often results in the patient's tendency to commit suicide as result of depression. In addition, about 30 percent of Malaysians suffer from mental illness especially women. This shows that mental illness is not a minor scale disease, but that it has begun to dominate the group of other diseases in the country.

Demands in the role of life greatly affect the mental pain of the human being. Emotional backgrounds and personality tensions have greatly contributed to the deterioration of human mental health. In addition, mental illness is regularly associated with emotional problems and negative personalities. Characteristically, individuals with mental health problems will quickly become irritated and mad. They do not think well and are continually drastic in making decisions (Yozgat, Yurtkoru \& Bilginoglu, 2013). More distinguished is that they act like humans in an out-of-control mentality. One of the most common actions is the destructive attitude of the objects around of them. It is more terrifying when they harass other people by hurting their friends or individuals around them (Zafir \& Fazilah, 2006).

According to the President of the Association of Public Service Psychologists (PSIPA), Dr Abdul Jalil Hassan, the problem of stress and mental illness is not new-fangled but it is a growing pain over time. In fact, a study conducted by the World Health Organization (WHO) shows that mental illness would be the leading cause by 2020. These statistics clearly show that mental illness is a very serious issue. Not just the community, mental illness also experienced by professional occupations including civil servants in Malaysia. In the Malaysian 
phenomenon, Siti Norshahidah's report (2019) found that 400000 civil servants suffered from anxiety disorders. This information shows that many mental illnesses occur in adults.

According to Noorhafeza and Ferlis (2010), the problem of insomnia is also a precursor to stress. Symptoms of insomnia because one gets a respectable night's sleep and are often disturbed. Because of this, the human brain under stress has a high rate of load and has to work overtime. The most common symptom of insomnia is that humans will experience extreme fatigue. Although the level of fatigue experienced is high, the patient is still unable to fade from the brain and his or her active mind from normal hours. Indirectly, it can cause other pain such as heart problems and headaches from chronic life disorders.

Suicide is a negative step that often occurs in stressful individuals. They have committed suicide as a solution to their problems. This is occurring among students. Learning pressures and financial problems on campus are the cause of students' suicide (Wan Noor Hayati, 2016). In fact, many teenagers today are caught up in the symptoms of suicide among overseas artists. Teenagers who are paranoid and obsessed with artists make suicidal ideation and initiative. It is evident on social media sites that many cases of suicide occur among overseas artists. The cause of suicide is the stress of life.

Aguglia et al. (2018) indication that the existence of personality disorder in a person's personality actually involves the feeling of daydreaming. This dizzying feeling related to the separation of thoughts and memories, feelings, actions that trigger various identities and personalities. This problem known as Dissociative Identity Disorder (DID). In dividends with DID are often variable and inconsistent. Sometimes they see a friendly and kind person. On the divergent, there are times when they act as irritated and very aggressive. In fact, this tendency is more prevalent in women than in men. The cause of DID is due to the emotional turmoil that has been experienced since childhood, and it has eventually become a gripping personality throughout adolescence and adulthood. However, several factors of DID are also identified through genetic, hormonal imbalance in the body and lifestyle imbalance.

In their report, Bauer et al. (2018) explain that there is also a mental illness associated with significant bipolar disorder. Bipolar is a two-dimensional disorder associated with depression in which one has a level of sadness and extreme levels of happiness. Extreme happy feelings category as 'mania phase' and if the symptoms are not dominant, they are simply known as 'hypomania'. This phase of emotional transition depends on an individual. There are individuals who are able to control emotions quickly and slowly. Typically, bipolar disorder occurs in individuals 18 years old (Bipolar I) and 20 years old (Bipolar II). The results of a study abroad have found that the prevalence of bipolar disorder is prevalent among women, young people and educated people (Gan et al., 2011).

\subsection{Family Experience Care for Mental Illness Person}

The process to comprehend and identify the implications of pressure, several forms of impact recognised. Signs of stress divided into several symptoms that involve physical, behavioural and psychological changes. In the context of the world of work, these vicissitudes can result in workplace accidents if left unchecked at work. Excessive stress at work can affect human health and well-being (Zafir \& Fazilah, 2006). In fact, it can also be life threatening if left unchecked and given treatment. When one is under severe stress, physiology, psychology and behaviour change drastically (Peterson \& Wilson, 2004). The main effects of stress are depression, negative emotions, anxiety, sadness, fatigue, muscle tension and so on.

Other ways to identify individuals for stress are through their healthiness. Depressed individuals will usually experience health problems such as severe cough, stomach or gastric problems, chronic headache or migraine and chest pain. Donald et al. (2005) also found that the effects and implications of stress are one of the causes of chronic illness. High levels of pressure can increase cholesterol levels in the bloodstream. Increased cholesterol be able to cause blood vessels to damage and to fail to function properly. Blood pressure and heart rate will also change due to extreme pressure.

In terms of emotional change, depressed individuals have an aggressive and impatient personality. They tend to be annoyed and less considerate of others (Cheng, Gou \& Yeh, 2001). This is due to the stress that the emotional, physical, and mental stress of a person's environment changes as opposed to their potential and self-efficacy. In fact, severe stress not only affects the short term, it can also lead to long-term problems (Isaac, 2003). However, the level of pressure depends on one's ability to handle the pressure. There are individuals who can deal with stress in a short period. On the other hand, there are individuals who have to deal with emotional pain and fatigue in the face of stress (Khairul Bariah, 2003). Prolonged stress contributes to chronic pain.

Other factors also emphasize the root cause of the problem of stress caused by family. Background studies show that stress is associated with family background factors, which often occur as a teenager. For example, a report prepared by Nurul Riduan (2019) shows that on May 14, 2019 there was a 16-year-old girl who committed suicide by jumping from a three-storey building in Kuching, Sarawak. It is even sadder when the teen commits suicide because of a poll sent on social media. This is due to the stress and depression that the teen faces and drives him to do the negative things.

This shows that stress is not only a result of work commitment, but it is due to an individual's background. In addition to family background or environment, genetic factors and natural mental disorders are also factors in a person's initial childhood stress. In a report written by Wan Noor Hayati (2015), he identified several types of diseases that seen as forms and symptoms of stress in children. 
Somebody is supposed to be under stress if have any signs of causing the disease. According to Md. Safian (2004), individuals who suffer from stress often have trouble forgetting and cannot focus on doing something. This is because emotions and minds are in an unstable environment. The mind is full of various questions and problems that cause an individual to suffer from mental and emotional disorders that have a negative impact on daily life, work performance and quality of assigned tasks.

All parties should emphasize the aspects of tranquillity and harmony in life in order to reduce stress. Chronic stress problems not only affect the emotional and physical wellbeing but also affect the lives of individuals. Destruction of family will also occur in the case of suicide among mental patients. Families are individuals who have to bear shame and their image is also affected in the long time phases. If suicidal mental patients have children, it can affect them emotionally. Their children have to accept negative perceptions of society and they may be associated with mental illness.

According to Firdaus who is the Secretary of the Malaysian Psychiatric Association in 2019, he found that stress had to addressed especially when it came to work. This phenomenon is particularly alarming as it reduces work motivation among workers. In Firdaus report (2019), the President of the Congress of the Union of Public Service Employees found that 20000 civil servants are retiring early due to workplace pressures in 2017. In its annual statistics, it shows great value as it involves 30000 to 35000 people. In this regard, employees are encouraged to find workarounds for coping with stress in the workplace including planning well. Workers are also encouraged to adopt a work-life balance system to avoid conflicts with family work (Firdaus, 2019).

Based on several reports and facts related to the problem of mental illness, it is clear that the group of mental patients is not of the same gender or less educated person. However, mental illness is also prevalent among the young, adolescents and the educated or rich person. In this look, we need to increase the number of psychiatrists to help more individuals receive optimal treatment (Nadia, 2017). Since mental illness is not a minor issue, it requires a variety of methods and approaches. One of the most common forms of approach is to provide advice and motivation. In addition, specialized treatments performed including the delivery of medicines and some methods of treatment using machines and technology equipment. For the Muslim community, they can get treatment through Islamic methods that emphasize spiritual and religious aspects. The concept of happiness and surrender to the destiny of God applied to the soul of every human being. Wellness is a symbol of emotional and physical health. The symbol of human strength measured through the face and body of the healthy through the normal mind.

\section{Research Methodology}

This study practices the critical analysis and library studies through systematic readings of data and secondary data findings. Few previous reports and studies identified and analysed as findings. However, the secondary data used still preserve the authenticity of previous studies and reports. The names of the authors and reporters cited as sources of reference and citations to the findings of the critical analysis conducted. The process of systematic literature review has a lot of reading, synthesis and review of research study were selected. The most importance for this method, we should know and find the gap of research such as the methodology and findings. According of the previous study, I am interested with four item whereby I discussed in my problem statement and literature review.

\section{Findings and Discussion of Critical Analysis in Systematic Literature Review 6.1 Concept and Monitoring of Mental Illness}

Mental illness classified as a problem involving brain disorders. The effects of mental illness involve changes in thinking processes; problems of temper and abnormal behaviour (see Figure 1). Implications of mental illness traced through interruptions and changes in one's daily activities (Mohd Nasir, 2012). In 1996, a study showed that almost 11.1 percent of adults in Malaysia suffer from mental illness. Additional troublingly, the World Health Organization reports that mental illness will be the second highest cause of disability in 2020.

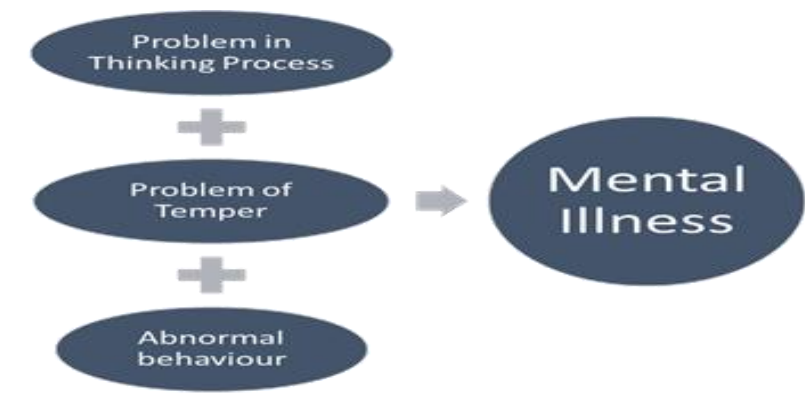

Figure 1: The Concept of Mental Illness (Source: Mohd Nasir, 2012)

\subsection{The Knowledge Level of Mental Health}

This second finding taken from a study conducted by Intan Nurhaila et al. (2011). Her research emphasized the importance of the level of knowledge related to mental health among public university students. Her research conducted at Universiti Kebangsaan Malaysia (UKM) involving 30 respondents between the ages of 20 and 25. According to her research, the level of knowledge of mental illness among respondents is low as the majority of them have low mean scores. In fact, correlation studies also showed insignificant findings where demographics 
did not affect knowledge on mental illness. Overall, Nurhaila et al. (2011) conclude that a major factor in the lack of knowledge about mental illness among students is due to communication and information that is still lacking in society especially students.

Table 1: Levels and Relationships of Knowledge with Student Demographics

Source: The study of Nurhaila et al. (2011)

\begin{tabular}{|c|c|c|c|c|}
\hline \multicolumn{2}{|c|}{ Demography } & \multicolumn{2}{|c|}{ Level of Knowledge } & \multirow[t]{2}{*}{ Correlation Value } \\
\hline & & High & Low & \\
\hline \multirow[t]{2}{*}{ Gender } & Female & 3 & 14 & \multirow[t]{2}{*}{0.527} \\
\hline & Male & 2 & 11 & \\
\hline \multirow[t]{2}{*}{ Race } & Malay & 5 & 20 & \multirow[t]{2}{*}{1.000} \\
\hline & Non-Malay & 0 & 5 & \\
\hline
\end{tabular}

Table 1 shows the findings of the study conducted by Nurhaila et al. (2011). This finding indicates that the level of respondent knowledge is low, especially for female students (14). There are 11 male students received low levels of knowledge related to mental illness. Only five people were highly knowledgeable about mental illness. In terms of people, the majority ethnic Malays have the low level of knowledge about the mental illness. However, the research show people who have not wither no high level of knowledge related to mental illness. Therefore, the results of the correlation studies showed that there was no significant relationship between demographics (gender and race) and knowledge level of mental illness among students. This is because the values obtained were not significant ( $\mathrm{p}>0.05)$.

\subsection{Schizophrenia Mental Disease Factors}

The findings conducted by Nur Aidaa, Faudziah and Syazwaan (2019). The findings show that there are four factors that cause schizophrenia, which are genetic factors, drug abuse factors, work stress factors and poverty factors. This study used qualitative techniques and used objective sampling techniques. The study population focused on patients with Mild Schizophrenia only. Out of 120 populations, Nur Aidaa, Faudziah and Syazwaan (2019) selected only four patients based on the approval of psychiatrists. The location of the study was at the Ipoh Perak Protection Canter.

Table 2: Factors for Mental Illness Schizophrenia

Sources: Nur Aidaa, Faudziah and Syazwaan (2019)

\begin{tabular}{|l|c|c|c|}
\hline Patient & Age & Schizophrenia Factor & Race \\
\hline Patient 1 & 51 years old & Genetic & Malay \\
\hline Patient 2 & 37 years old & Drug Abuse & Malay \\
\hline Patient 3 & 40 years old & Work Stress & Malay \\
\hline Patient $\mathbf{4}$ & 65 years old & Poverty & Indian \\
\hline
\end{tabular}

Table 2 shows the findings of the study obtained by Nur Aidaa, Faudziah and Syazwaan (2019) while conducting a study on schizophrenic mental patients. According to Kaplan et al. (2010), Schizophrenia is a type of mental illness that involves changes in behaviour. Table 2 is four patients who categorized as mild schizophrenia by psychiatrists. The scale of the age of the patient is within the range of 37 to 65 years, of which three are Malays and only an Indian. The first patient was a Malay who is a 51-year-old patient caused by genetic factors. Genetic factors are inherently difficult to overcome because they acquired through family and genetic. Genetic factors also occur in childhood or adolescence. The second patient was 37 years old and Malay. The second patient diagnosed with a substance abuse problem. The problem of uncontrolled drug abuse fact be detrimental to a person's mental, emotional and behavioural health even at a young age. The third patient also Malays and 40 years old. As noted in the literature review, the major factor in mental illness in society is due to excessive work pressure. Excessive work stress can reason a person to lose control of his or her well-being and thus experience depression. The fourth patient was a 65-year-old Indian. The problem that these patients face is the poverty factor. Poverty is a major issue in human life. Poverty is also strongly associated with socialization because it involves other communities. The attitude of some people who often insult and marginalize the poor causes the depressed and miserable individuals to suffer.

\subsection{Family Experience Care for Mental Illness Person}

Table 3: Experiences of Mental Health Care

Source: Mohd Suhaimi (2015)

\begin{tabular}{|l|c|c|}
\hline Experience & Urban & \multicolumn{2}{|c|}{ Rural } \\
\cline { 2 - 3 } & \multicolumn{2}{|c|}{ Mean Value } \\
\hline Patients negative behaviour & 1.24 & 1.17 \\
\hline
\end{tabular}




\begin{tabular}{|l|c|c|}
\hline Negative symptoms of patient & 1.86 & 1.34 \\
\hline Stigma & 1.12 & 1.41 \\
\hline Problems with the service & 1.44 & 1.49 \\
\hline Impact towards family & 1.13 & 1.47 \\
\hline Patients dependency & 1.65 & 1.65 \\
\hline Positive personal experience & 2.54 & 0.69 \\
\hline Good relationship with the patients & 2.34 & 0.87 \\
\hline
\end{tabular}

This study conducted by Mohd Suhaimi et al. (2015) on 154 mental health care workers. Mohd Suhaimi et al. (2015) conducted a survey using questionnaire form. The questionnaire instrument consisted of 66 items measuring the level of experience of caring for families with mental illness. A number of experiences mentioned in the study. Table 3 shows some of the experiences experienced by the caregiver.

Based on Table 4, Mohd Suhaimi et al. (2015) found that some of the experiences of the caregivers of mental patients consisted of the patient's family. He has also conducted comparative studies between the caregivers of mental patients in urban and rural areas. Mental caregivers in urban areas indicated that they had a higher positive personal experience with patients compared to carers of rural mental patients clearly indicating that their relationship with patients was very low with a mean value (0.69). In fact, the caregiver's relationship with the patient is also categorized as higher in the urban area than in the rural areas (mean $=2.34$ and mean $=0.87$ ). Generally, a study conducted by Mohd Suhaimi (2015) clearly shows that patient care in urban areas is more positive than in rural areas about the mentall illness perceptions.

\section{Conclusion}

Mental illness is a disorder that be existent in society regardless of age, race, educational background, and status or luxuriant. Therefore, individuals with mental disorders encouraged to get a psychiatrist or referred to as a therapist. The competencies and abilities possessed by psychiatrists are crucial in guiding patients to optimum healing (Siti Nur Shahidah, 2019). Based on the discussion in this study, it clearly shows that mental illness related to brain problems, thoughts, emotional disorders and eventually depression and sadness. If the patient does not control their disease effectively, it will cause the patient to become more dangerous and eventually contribute to suicide.

Emotional tension and negative behavioural transformation influenced by psychological elements. According to Nur Aidaa, Faudziah and Syazwaan (2019), these psychological elements include psychological distress, emotional turmoil, and extreme personality disorder. In the long term, it can contribute to the risk of diseases including heart disease, hypertension and other diseases. In terms of quality of life, several mental patients suffer from job dissatisfaction, conflicts with their employer or co-workers. The quality of life with the family is also affected. In fact, there are patients who have to break up with their partner due to the stress of being large and affecting their family (Gallie, 2009).

The role of the Ministry of Health (MOH) is very important in addressing and reducing the risk of mental illness. These include positive and motivational programs that can change a patient's awareness toward healthy sophisticated. Many psychologists assert that the main source of mental illness is emotional sickness. A healthy is constantly in a smiling, organized environment and does not feel pressured by any person or individual. Considering the high risk of mental illness associated with the suicide phenomenon, this proves that the pain is not a comedy on the mind or the concentration. Mental illness is not just an illusion or conceptual delusion, but it is a fact that functionally confirmed. Therefore, all gatherings prerequisite to act holistically to ensure that humanity is healthy and able to develop a generation with constant sentiments and a customary excellence of lifetime.

\section{Acknowledgement}

Appreciations to all authors and researchers who contributed their philosophies to this paper. Thanks also to the University of Tun Hussein Onn Malaysia (UTHM) for the sponsorship provided for this publication.

\section{Reference}

1. Aguglia, A., Mineo, L., Rodolico, A., Signorelli, M. S., \& Aguglia, E. (2018). Asenapine in the Management of Impulsivity and Aggressiveness in Bipolar Disorder and Comorbid Borderline Personality Disorder: An Open-Label Uncontrolled Study. International Clinical Psychopharmacology, $33,121-130$.

2. Alina Z. Levine, Rawya Aljabari, Kristy Dalrymple \& Mark Zimmerman (2020). Nonsuicisal Self-Injury and Suicide: Differences between those with and without Borderline Personalitu Disorder. Journal of Personalitu Disorders, 43 (1), 131-144.

3. Asri Marsidi \& Hamrila Abdul Latip. (2007). Faktor-Faktor Yang Mempengaruhi Komitmen Pekerja di Organisasi Awam. Jurnal Kemanusiaan, 10.

4. Azlina Abu Bakar. (2012). Psikologi Industri dan Pengurusan Sumber Manusia. Terengganu: Universiti Malaysia Terengganu. 
5. Bauer, M., Andreassen, O. A., Geddes, J. R., Vedel Kessing, L., Lewitzka, U., Schulze, T. G., \& Vieta, E. (2018). Areas of Uncertainties and Unmet Needs in Bipolar Disorders: Clinical and Research Perspectives. The Lancet Psychiatry, 5, 930-939.

6. Cheng, Guo \& Yeh (2001). A National Survey of Psychosocial Job Stressors and their Implications for Health among Working People in Taiwan. International Archives of Occupational Environmental Health, 74, 495-504.

7. Donald I, Taylor P, Johnson S, Cooper C, Cartwright S \& Robertson S (2005). Work Environments, Stress and Productivity: An Examination Using Asset. International Journal of Stress Management, 12(4), 409-423.

8. Firdaus Abdul Gani (2019). Hari Kesihatan Mental Sedunia 2019: Promosi Kesihatan Mental dan Pencegahan Bunuh Diri. Astro Awani, 10 Oktober 2019. Retrieved at

9. http://www.astroawani.com/berita-malaysia/hari-kesihatan-mental-sedunia-2019-promosi-kesihatanmental-dan-pencegahan-bunuh-diri-219627 on 12 July 2020.

10. Firdaus Abdul Gani (2019). Tekanan di Tempat Kerja: Bagaimana untuk Bertahan. Astro Awani 21 Februari 2019. Retrieved at http://www.astroawani.com/berita-malaysia/tekanan-di-tempat-kerjabagaimana-untuk-bertahan-199233 on 5 July 2020.

11. Gallie D, Russell H (2009) Work-family Conflict and Working Conditions in Western Europe. Social

12. Indicators Research, 93(3), 445-467.

13. Gan, Z., Diao, F., Wei, Q., Wu, X., Cheng, M., Guan, N. \& Zhang, J. (2011). A Predictive Model for Diagnosing Bipolar Disorder Based on the Clinical Characteristics of Major Depressive Episodes in Chinese population. Journal of Affective Disorders, 134, 119-125.

14. Intan Nurhaila Meor Safari, Norlija Kassim, Nur Falihin Iskandar, Mohamad Haazik Mohamed \& Mohd Yusof Abdullah (2011). Level of Knowledge on Mental Health among IPTA Students: Case Study in UKM, Bangi. Jurnal Personalisa Pelajar, 14, 37-44.

15. Ishak Md. Shah. (2003). Pengenalan Psikologi Industri dan Organisasi. Skudai: Universiti Teknologi Malaysia.

16. Ismail A, Abu H. N, Chin Y. F, Ismail Y, Abu S. A. J. (2013) Job Stress as a Predictor of Employee Health. Studies in Business and Economics, 8, 20-34.

17. Kamus Dewan (1984) Edisi Kedua. Dewan Bahasa dan Pustaka, Kuala Lumpur.

18. Kaplan, H.I., Saddock, B. J. \& Grebb, J.A. (2010). Kaplan-Sadock Sinopsis psikiatri ilmu pengetahuan prilaku psikiatri klinis. Buku Penerbitan, Tangerang: Bina Rupa Aksara, 1-8.

19. Khairul Bariah Ishak. (2003). Tekanan Kerja, Kepuasan Kerja, Strategi Daya Tindak,Kesihatan Mental dan Kesihatan Fizikal di Kalangan Jururawat. Latihan Ilmiah. Universiti Kebangsaan Malaysia

20. Lazarus, R. S. (1990) Psychological Stress and the Coping Prosess. New York Springer Publishing Company.

21. Masilamani, R., Bulgiba, A., Chinna, K., Darus, A., Isahak, M., Kandiben, S., \& Koh, D. (2013). Prevalence and Associated Factors of Stress in the Malaysian Police Force. ScienceDirect - Preventive Medicine, 57, S57-S59.

22. Md. Safian Bin Mohd Tajuddin. (2007). Kesan Aspek Kesihatan Terhadap Produktiviti Kerja dalam Kalangan Pensyarah. Maktab Perguruan. Universiti Sains Malaysia.

23. Mohd Nasir Abd Kadir (2012). Penyakit Mental. Kementerian Kesihatan Malaysia, 20 April 2012. Retrieved at http://www.myhealth.gov.my/penyakit-mental/ on 17 July 2020.

24. Mohd Suhaimi Mohamad, Nasrudin Subhi, Fauziah Ibrahim \& Khadijah Alavi (2015). Pengalaman Keluarga Menjaga Pesakit Mental: Satu Kajian Perbandingan Komuniti Bandar dan Luar bandar di Perak dan Kedah. Malaysian Journal of Society and Space, 11, 23-31.

25. Mojoyinola J.K. (2008) Effects of Job Stress on Health, Personal and Work Behavior of Nurses in Public

26. Hospitals in Ibadan Metropolis, Nigeria. Studies on Etho Medicine, 2(2),143- 148.

27. Nadia Hamid (2017). Malaysia Kekurangan Pakar Psikologi. Berita Harian Online, 1 July 2017. Retrieved at https://www.bharian.com.my/berita/nasional/2017/07/297876/malaysia-kekurangan-pakar-psikologi on 15 July 2020.

28. Noorhafeza Herliani Adey \& Ferlis Hj. Bahari (2010) Hubungan Antara Kecerdasan Emosi, Kepuasan Kerja Dan Komitmen Terhadap Organisasi. Jurnal Kemanusiaan,16.

29. Noraini Abdul Raop \& Noorasmah Bakri (2019). Tekanan Kerja: Hubungannya dengan Komitmen Organisasi dalam Kalangan Anggota Bomba dan Penyelamat. Alor Gajah, Melaka. Jurnal Sains Sosial, 4(1), 54-67.

30. Nurul Riduan (2019). Depresi Pembunuh Senyap Remaja Malaysia. Sinar Harian, 21 Mei 2019. Retrieved at https://www.sinarharian.com.my/article/29093/SUARA-SINAR/Analisis-Sinar/Depresi-pembunuhsenyap-remaja-Malaysia on 8 July 2020.

31. Nur Aidaa Mohd Ali, Faudziah Yusof \& Syazwan Aziz (2019). Faktor-faktor Penyebab Penyakit Skizofrenia: Satu Kajian Kes. Malaysian Journal of Social Science, 4(1), 68-79. 
32. Nur Izzaty Mohamad, Azman Ismail, Mohamad Shahril Azwan Mohamad Rozi \& Sholihien Ahmad (2015). Tekanan Kerja dan Perkaitannya dengan Kesihatan Pekerja: Kajian Empirikal Sebuah Kontinjen Polis di Semenanjung Malaysia. Malaysia Journal of Society and Space, 11 (10), 63-75.

33. Nursyazlin Yatie Mohd Zaidi \& Noraini Abdol Raop (2017). Faktor-faktor yang Mempengaruhi Tekanan Kerja dalam Kalangan Anggota Polis: Satu Kajian di Kem Batalion 9 PGA Kuala Terengganu. Jurnal Sains Sosial, 3, 103-116.

34. Peterson M \& Wilson J.F (2004). Work Stress in America. International Journal of Stress Management, 11(2), 91-113.

35. Salmah Othman (2009). Kecerdasan Emosi dan Tekanan Kerja serta Hubungannya dengan Komitmen Kerja Dalam Kalangan Anggota Polis Diraja Malaysia. (Tesis Sarjana). Universiti Utara Malaysia, Sintok, Kedah, Malaysia.

36. Siti Aisyah Sukaimi (2019). Keinginan Remaja Bunuh Diri Meningkat. MyMetro 10 September 2019. Retrieved at https://www.hmetro.com.my/mutakhir/2019/09/495175/keinginan-remaja-bunuh-dirimeningkat on 5 July 2020.

37. Siti Nursyahidah Abu Bakar (2019). Jumlah Pekerja Tertekan Meningkat Jika Tak Ditangani. Berita Nasional 19 Mac 2019. Retrieved at

38. https://www.sinarharian.com.my/article/19036/BERITA/Nasional/Jumlah-pekerja-tertekan-meningkatjika-tak-ditangani on 5 July 2020.

39. Wan Noor Hayati Wan Alias (2016). Gejala Penyakit Mental: usia 10 Tahun Cuba Bunuh Diri. Berita Harian Online 3 September 2016. Retrieved at

40. https://www.bharian.com.my/bhplus-old/2016/09/189284/gejala-penyakit-mental-usia-10-tahun-cubabunuh-diri on 5 July 2020.

41. Wan Noor Hayati Wan Alias (2016). Gejala Pelajar Sakit Mental Merisaukan. Berita Harian Online, 2 September 2016. Retrieved at https://www.bharian.com.my/bhplus-old/2016/09/188987/gejala-pelajarsakit-mental-merisaukan on 28 June 2020.

42. Yozgat, U., Yurtkoru, S., \& Bilginoglu, E. (2013). Job Stress And Job Performance Among Employees in Public Sector in Istanbul: Examining The Moderating Role of Emotional Intelligence.Social and Behavioral Sciences, 75(0), 518-524 